\title{
Tradycja dziewiętnastowieczna w lustrze współczesnego komiksu polskiego. Kilka uwag o Pierwszej brygadzie i Romantyzmie
}

Bartłomiej Szleszynski 
nAP7S Seria XIV 2008

\author{
Bartłomiej Szleszyński
}

\title{
Tradycja dziewiętnastowieczna w lustrze współczesnego komiksu polskiego. Kilka uwag o Pierwszej brygadzie i Romantyzmie
}

$\mathrm{W}$

jednej ze scen komiksu Prawie 48 stron, kolejnej części parodii motywów współczesnej kultury popularnej, widzimy żartobliwie przedstawioną Ligę Polskich Niezwykłych Dżentelmenów. Tworzą ją między innymi: Doktor Judym (pseudonim Doc), Antek (geniusz techniczny), Siłaczka (zbrojne ramię grupy), Latarnik (chodzący bank danych) ${ }^{1}$. To oczywiście nie postaci znane nam z lektur, lecz takie, jakie można by wyobrazić sobie w uniwersum (zachodniej) literatury popularnej — Judym wygląda jak mroczny medyk-skrytobójca, Latarnik to szalony naukowiec, Antek - mechanikwynalazca. Ten kadr to jedynie żart, lecz wbrew pozorom niezwykle wymowny i mówiący wiele o popularnym wyobrażeniu polskiej literatury XIX wieku.

Aby to w pełni zrozumieć, należy powiedzieć dwa słowa o „oryginalnej” Lidze Niezwyktych Ḋ̇entelmenów ${ }^{2}$. Komiks ze scenariuszem Alana Moore’a (autora takich wybitnych utworów jak chociażby Strażnicy czy $V$ jak Vendetta), to erudycyjna i pomysłowa gra elementami dziewiętnastowiecznej kultury popularnej. Do tytułowej ligi należą Alan Quatermain, Mina Harker z Draculi Stokera, Dr. Jekyll (i Mr. Hyde w jednym), Niewidzialny Człowiek oraz kapitan Nemo. Bohaterowie spotkają na swojej drodze między innymi: Augusta Dupina, doktora Moreau, profesora Moriarty'ego i Wellsowskich kosmitów.

Jak widać z powyższego wyliczenia (bardzo niepełnego zresztą) bohaterów utworu, jego twórcy pełnymi garściami czerpią z dziewiętnastowiecznej kultury popularnej.

\footnotetext{
${ }_{1}^{1}$ Zob. T. Piątkowski, R. Adler, Prawie 48 stron: Maciek / Komix: Rewelacja, Wrocław 2004, s. 12.

${ }^{2}$ A precyzyjniej - o jej pierwszych dwóch tomach. Planowany jest także tom 3, zaś pod koniec 2007 roku wyszedł album The Black Dossier, którego akcja toczy się w latach pięćdziesiątych XX wieku.
} 
Zdecydowanie wykraczaja jednak poza poziom płytkiej anegdoty — utwór cechuje się ogromną dbałością o dziewiętnastowieczne realia literackie. Widać to już w samej formie komiksu, który podany jest w żartobliwie potraktowanej formule zeszytowych wydawnictw popularnych ${ }^{3}$ - każdy $z$ zeszytów zawiera także między innymi fikcyjne reklamy $z$ epoki i tak samo fikcyjne listy od czytelników. Kolejne plansze aż gęste są od stylowych „smaczków” i odniesień do dziewiętnastowiecznej literatury, starannie dopracowano nawet takie szczegóły jak rodzaje rewolwerów używanych przez Quatermaina i Dupina. Każdy z zeszytów kończy się stylowym zwrotem do czytelnika połączonym z zachętą do kupna kolejnej jego części - oto przykładowy fragment:

Zadrżyj, miły Czytelniku, na ten straszliwy widok. Oto Johnny Chińczyk, uzbrojony w potężną broń nowej ery elektrycznej, zamierza użyć jej przeciwko naszej wyspiarskiej ojczyźnie! Czy ktokolwiek zdoła zniweczyć te ohydne plany? Nie zapomnij zamówić z góry następnej części naszej ilustrowanej książki dla chłopców, by poznać dalszy ciąg tej fascynującej opowieścit.

Co ważne, osią akcji jest to, czym zazwyczaj zajmują się bohaterowie powieści popularnych - w części pierwszej walczą z tajemnym spiskiem złoczyńców kierowanym przez geniusza zbrodni, w części drugiej muszą poradzić sobie z najazdem kosmitów.

Utwór zawiera także wiele elementów nurtu fantastyki nazwanego steampunk warto w tym miejscu objaśnić termin, który powróci jeszcze w moim tekście. Tak definiują go twórcy zajmującego się tym zjawiskiem portalu internetowego „Retrostacja”:

To współczesny nurt fantastyki, sięgający do samych korzeni science fiction — do XIX-wiecznej powieści naukowej [...], XVIII-wiecznego gotyckiego horroru i pulp fiction z początków XX wieku. Wszystko to, czego Juliusz Verne, H.G. Wells i Sir Arthur Conan Doyle nie zdążyli wymyślić $[\ldots]$ dziś nadrabiają steampunkowcy ${ }^{5}$.

A tak objaśnia termin Wojciech Orliński:

Steampunk to modny od niedawna gatunek fantastyki, w której współcześni autorzy umieszczają akcję w XIX wieku, opisując fabularne schematy typowe dla współczesnej fantastyki, ale zrealizowane za pomocą ówczesnej techniki. W steampunku mamy więc np. roboty napędzane parą i komputery zbudowane ze stalowych trybików ${ }^{6}$.

${ }^{3}$ Niestety, w polskiej edycji pominięto większość dodatków tego typu.

${ }^{4}$ A. Moore, K. O’Neill, Liga Niezwykłych Dżentelmenów, t. 1, Warszawa 2003, kadr kończący część III.

${ }^{5} \mathrm{http} / / /$ steampunk.republika.pl/defin01.html (stan z dnia 4 listopada 2008).

"W. Orliński, Staś, Nel i roboty na pare, "Gazeta Wyborcza” z 28 maja 2006. 
W Lidze... spotkamy wiele tajemniczych wynalazków i modyfikacji dziewiętnastowiecznej rzeczywistości — oprócz znanego nam z „oryginalnej” literatury statku kapitana Nemo, w pierwszej części widzimy na przyklad maszyny latające i będący na ukończeniu most nad kanałem La Manche.

O tym dziele i sposobie, w jaki gra ono $z$ dziewiętnastowieczną kulturą popularną, można by z pewnością napisać nie artykuł, lecz książkę, podobnie jak o innych wybitnych zachodnich komiksach prowadzących dialog z dziewiętnastowiecznością7. Co istotne, Ligę.. odbierać można na kilku poziomach, zależnie od kompetencji czytelniczych - przy najmniejszych odbiorca rozpozna tylko najprostsze odniesienia literackie, próba odczytania wszystkich odniesień zawartych w Lidze... kończy się kilkudziesięcioma stronami przypisów ${ }^{8}$.

W tym miejscu warto wspomnieć nawiasowo o szerszym zjawisku, którego Liga... jest elementem. Kultura współczesna prowadzi wiele gier $z$ dziewiętnastowiecznością czy też ze współczesnymi wyobrażeniami o niej. Na Zachodzie zjawisko to widać w wielu dziedzinach — od ogromnej liczby tekstów naukowych i popularnonaukowych, poprzez tzw. literaturę wysoką, aż po sporą liczbę dzieł kultury zwyczajowo nazywanej popularną - książek, filmów, gier komputerowych czy nawet stylizowanych na dziewiętnastowieczne reklam współczesnych produktów. W Polsce obserwować możemy to zjawisko głównie w obrębie literatury — jako dialogu idei postmodernistycznych z modernizmem, maski dziewiętnastowiecznej nakładanej na dylematy współczesności bądź też mniej lub bardziej świadomego wykorzystania dziewiętnastowiecznych klisz literackich i konstruktów myślowych. Wydaje się jednak, że w Polsce owe tendencje nie wychodziły przez dłuższy czas poza literaturę nieelitarną.

Odpowiedź na pytanie, dlaczego tak się stało, daje nam owa, przywołana na wstępic wystąpienia, żartobliwa wizja polskiej Ligi Niezwyktych Dżentelmenów.

Otóż po pierwsze - w przeciwieństwie do Anglików nie posiadamy zakorzenionych w masowej wyobraźni wyrazistych postaci z rodzimej kultury popularnej — przez wiek XIX byliśmy raczej konsumentami, kompilatorami i plagiatorami popularnych tekstów zagranicznych. Po drugie — postaci z dziewiętnastowiecznej literatury, które jakoś w polskiej masowej wyobraźni funkcjonują, to przeważnie bohaterowie lektur szkolnych, którzy w zasadzie nie bardzo nadają się, aby umieścić ich w uniwersum rodem z powieści popularnej. I sprawa trzecia — oś akcji rodzimych tekstów dziewiętnastowiecznych była zawsze związana w jakiś sposób z Polską (w wariantach „,bić się czy nie bić” czy też ,jakiej

\footnotetext{
7 Wymienić tu można choćby przeznaczoną dla dorosłych serię Piotruś Pan Regisa Loisela czy liczne motywy dziewiętnastowieczne w dziełach Enki Bilala.

8 W Internecie przypisy do Ligi... znaleźć można pod adresem: http://www.geocities.com/Athens/ Olympus/7160/league1.html, wydane zostały także w formie książkowej (zob. J. Nevins, Heroes \& Monsters: The Unofficial Companion to the League of Extraordinary Gentlemen - ze wstępem Alana Moore'a i komentarzem Kevina O' Neilla).
} 
cywilizacji Polacy potrzebują"), co czyni zachodnie schematy literatury popularnej niezbyt przystającymi do masowych wyobrażeń o polskim wieku XIX.

Przywołany kadr z komiksu Prawie 48 stron zdaje się sugerować nie tylko brak polskiej Ligi Niezwykłych Dżentelmenów, ale w pewnym sensie niemożność jej utworzenia. Faktem jest, że w 2004 roku nie istniały komiksy starające się podejmować dialog z polską dziewiętnastowieczną kulturą, choć bawiono się dziewiętnastowiecznością w wydaniu zachodnim — seria Josephine łączyła brytyjski kryminał z klimatem kolonialnego horroru i powieści grozy, zaś komiks Pattern to paryska antyutopia w stylu steampunk.

W 2007 roku opublikowano jednak dwa utwory, które pokazały, że i w polskiej kulturze nieelitarnej możliwy jest dialog z polską dziewiętnastowiecznością, a nawet podjęcie $z$ nią interesującej gry.

Pierwszy z nich to komiks okrzyknięty "polską Liga Niezwyktych Dżentelmenów" i przyjęty przez recenzentów (również zajmujących się głównymi nurtami) jednoznacznie pozytywnie. Mowa o pierwszym tomie serii Pierwsza brygada zatytułowanym Warszawski pacjent, ze scenariuszem Janusza Wyrzykowskiego i Tobiasza Piątkowskiego oraz rysunkami Krzysztofa Janicza. Komiks ten rozpoczął swój żywot w Internecie, na stronach portalu „Retrostacja”. Powielono w nim sposób nadania dziełu dziewiętnastowiecznej patyny wykorzystany w Moore'owskiej Lidze... (fragment komiksu ukazał się jako „nowe odkrycie” w magazynie „Piechur”), w warstwie graficznej oddano też klimat pism sprzed pierwszej wojny światowej (choć publikacja była oczywista grą z czytelnikiem — owe niby odkryte numery „Piechura” publikowano jedynie $\mathrm{w}$ Internecie).

Oczywiście, z przyczyn, o których już wspominałem, nie mógł powstać komiks podejmujący grę z rodzimą dziewiętnastowieczną kulturą popularną - po prostu nie bardzo miał on z czym grać. Ale twórcy Pierwszej brygady przezwyciężyli problemy stojące przed polską odpowiedzią na Lige Niezwyktych Dżentelmenów. Stworzyli komiks prowadzący dialog z popularnymi wyobrażeniami o wieku XIX.

Jego bohaterowie to postaci mocno zakorzenione w polskiej świadomości - literackiej (jak przedstawieni wiele lat po zakończeniu akcji Lalki czy $W$ pustyni $i$ w pusz$c z y$ - Stanisław Wokulski i Staś Tarkowski) oraz historycznej (jak Józef Piłsudski). Zauważmy, że wszystkie trzy postaci, oprócz tego, że są powszechnie znane, posiadają również duży potencjał, który można wykorzystać w tekstach popularnych — wątek „metalu lżejszego od powietrza” kojarzy się wprost z dziewiętnastowieczną fantastyką naukową, Staś Tarkowski to pelnokrwisty bohater przygodowy, a oglądany w tym kontekście życiorys Piłsudskiego to materiał na niezwykłą powieść awanturniczą.

\footnotetext{
${ }^{9}$ Zob.m.in.:http://komiks.nast.pl/artykul/2812/Pierwsza-Brygada-na-dywaniku-wywiad-z-tworcami/ czy http://www.kulturaonline.pl/Pierwsza,brygada,-,steampunk,po,polsku,tytul,artykul,2109.html.
} 
Główna intryga zakorzeniona jest w historii i opisuje walkę głównych bohaterów z zaborcą, co w opowieści o polskim wieku XIX wydaje się jedynym sensownym rozwiązaniem.

Akcja zaczyna się w 1901 roku, gdy Piłsudski poddawany jest badaniu psychiatrycznemu przez Rosjan - opowiada on lekarzom o spotkaniu ze Stasiem Tarkowskim, jego latającą maszyną, wiernym czarnoskórym sługą Kalim, a także o ataku polskich partyzantów-Sybiraków pod dowództwem generała Korczyńskiego i kwatermistrza Bohatyrowicza na tajną rosyjską stocznię balonów pancernych. Główny bohater uznany zostaje oczywiście za wariata, a później, wykradziony ze szpitala psychiatrycznego przez Stasia, ucieka przy użyciu machiny - samochodu-amfibii przed ścigającym go rosyjskim cyborgiem, ukrywającym się pod postacią generała Szutrynowicza "Szuta”. W końcu bohaterowie przybywają na gigantyczny okręt „Izabela”, na którym Wokulski prowadzi negocjacje z Japończykami.

Utwór wymyślony i narysowany jest bardzo starannie, z dużą dbałością o szczególy zarówno w warstwie fabuły, jak i grafiki. Podobnie jak Liga Niewykłych Dżentelmenów może być odbierany przynajmniej na dwóch poziomach — podstawowym, na którym nieznający wieku XIX czytelnik rozpozna jedynie podstawowe postaci i motywy oraz wyczuje steampunkowy klimat, a także - zaawansowanym, na którym zrozumieć można wszystkie dziewiętnastowieczne „smaczki”. Nie każdy doceni wszakże wpisanie wydarzeń w autentyczny życiorys Piłsudskiego, fakt, że maszyny latające podpisane są po rosyjsku „Geist” i że kilkakrotnie autorzy podśmiewają się z wypartych z powszechnej historycznej świadomości socjalistycznych poglądów marszałka ${ }^{10}$. Zapewne te $\dot{z}$ nie każdego czytelnika zdziwi fakt, że na kartach komiksu spotykamy Jerzego Bohatyrowicza i Andrzeja Korczyńskiego. Tajemnica, jak owi nieobecni, a właściwie martwi bohaterowie Nad Niemnem dostali się na Syberię, zostaje wyjaśniona dopiero w dołączonym na końcu liście Tarkowskiego do Piłsudskiego:

Liczę na dyskrecję oraz „gentlemen's agreement” w pewnej delikatnej kwestii. Otóż panowie Korczyński i Bohatyrowicz pozostawili nad Niemnem nie tylko wspólną powstańczą mogiłę, ale i pogrążone w smutku wdowy. Rozumiesz zatem, że dla uniknięcia skandalu ich syberyjskie przygody (osobliwie zaś buriackie familie) pozostać muszą tajemnicą ${ }^{11}$.

Oczywiście, Pierwszej brygady nie sposób zupełnie serio porównywać z Liga Niezwykłych Ḋ̇entelmenów - jej twórcy nie mieli szans konkurować z Alanem Moorem gęstością dziewiętnastowiecznych odniesień, nie tylko ze względu na geniusz

${ }_{10}$ Zob. m. in.: J. Wyrzykowski, K. Janicz, T. Piątkowski, Pierusza brygada, t. 1: Warszawski pacjent, Warszawa 2007, s. 40.

${ }^{11}$ Ibidem, s. 48. 
Anglika, ale też przede wszystkim na uwarunkowania rynkowe - jako komentarz posłużyć może wypowiedź jednego z twórców, że „honorarium za Warszawskiego pacjenta ledwo pokryło moje wydatki na materiały źródłowe" ${ }^{12}$. Bez wątpienia jednak ich tekst stoi na wysokim poziomie i jest świadectwem, że możliwa jest gra $z$ dziewiętnastowieczną tradycją (i to reprezentowaną przez uznawaną powszechnie za wyjątkowo nudną literaturę okresu pozytywizmu) we współczesnej kulturze nieelitarnej.

Drugi z tekstów podejmujących komiksowy dialog $z$ dziewiętnastowiecznością to Romantyzm Grzegorza Janusza i Krzysztofa Gawronkiewicza. Utwór ten to $z$ kolei gra $z$ romantycznymi wyobrażeniami o literaturze, jej powinnościach i przeznaczeniu, dyskusja o kulturze elitarnej i popularnej, a wreszcie satyra na polski stosunek do tradycji.

Protagonistą jest prywatny detektyw Otto Bohater wspomagany w swoich dochodzeniach przez szczura Watsona. Są oni znani z tomu Esencja, podobnie jak postać Aptekarza - zmarłego geniusza, który wynalazł metodę skraplania literatury, by była łatwiej przyswajalna. Tam odniesienia do dziewiętnastowiecznej literatury pozostawały na poziomie (niezłej zresztą) anegdoty — tom Romantyzm w całości poświęcony jest dialogowi z dziewiętnastowieczną tradycją romantyczną, a raczej z tym, co z owej tradycji uczyniono.

Jako przedstawiciele i uosobienie romantycznej „sztuki wysokiej”, ambitnej i zaangażowanej, mającej pełnić funkcje narodowego misterium, występują tu z jednej strony krytyk literacki, z drugiej zaś Minister Kultury.

Ten pierwszy to prezentuje model tradycjonalnego podejścia do literatury. Żyje on w zamkniętym świecie dzieł romantycznych — nosi t-shirt z Mickiewiczem, mieszka pod numerem 44, w domu oprócz biblioteki dzieł romantycznych ma reprodukcje (z ducha romantycznych przecież) dzieł Matejki - czytuje tylko „Życie Kulturalne” i ciągle wspomina, że dostał swój zegarek w nagrodę od Ministra Kultury za wypracowanie o romantyzmie. Oburzają go wszelakie przejawy kultury nie-romantycznej, a nawet wszelkie przejawy braku kultu dla twórczości romantycznej, na przykład gołębie siedzące na pomniku Chopina uważa za profanację, podobnie jak palmę na rondzie de Gaulle'a:

Czyż nie piękniejsza nasza poczciwa brzezina? [...]

Co to za drzewo?! Nie dość, że z plastiku, to ani się na tym powiesić, ani porządnego kija z tego uciąć ${ }^{13}$.

O powinnościach sztuki mówi:

12 http://komiks.nast.pl/artykul/2812/Pierwsza-Brygada-na-dywaniku-wywiad-z-tworcami.

${ }^{13}$ K. Gawronkiewicz, G. Janusz, Romantyzm, Warszawa 2007, s. 11. 
Młodzież się wygłupia, a sztuka powinna zachwycać i przerażać. Sztuka to najważniejsza rzecz na świecie. [...] Niektórzy oddali życie dla sztuki ${ }^{14}$.

Nie lubi przeklinania, oburza go kultura popularna - zarówno literatura, jak i kino. Nawet pomysł skraplania literatury, by była łatwiej przyswajalna, wydaje mu się oburzający:

A gdzie zapach papieru i druku, gdzie szelest przewracanych stron? [...] Nie można przyswajać sztuki bez wysiłku, tak. jak nie można jej tworzyć bez wysiłku!!! Sztuka wymaga poświęceń!!! ${ }^{5}$

To wyraziciel obecnych w naszej kulturze poglądów, które lączą w sobie niechęć do awangardy, pogardę wobec kultury popularnej i obawę przed humorem, komizmem i brakiem powagi w dziełach sztuki. Sztuka, zwłaszcza romantyczna, w tej perspektywie nie może, a nawet nie powinna dawać przyjemności, nie powinna również wywoływać miłych skojarzeń - jest powinnością, poświęceniem, wysiłkiem, narodową świętością.

Nasz krytyk przedstawiony jest jako słabowity i roztargniony grubasek, więc swoją złość wyrażać może jedynie wściekłymi tyradami. Jednak w świecie utworu spotykamy się z logicznymi konsekwencjami tych poglądów — spokojna opowieść zamieni się bowiem w horror. Nowy Minister Kultury wciela w życie śmiały projekt wskrzeszenia romantycznych mistrzów przy pomocy najnowszej techniki. W wywiadzie telewizyjnym mówi:

Wskrzesiliśmy ich, korzystając z prasłowiańskich, rzec by można, metod wspartych najnowszymi zdobyczami nauki w dziedzinie genetyki [...]. Nasze działania są bardzo kosztowne, w związku z tym liczymy na ofiarność społeczeństwa [...].

Mistrzowie dadzą nam Piękno i Prawdę. Ich dzieła są nieśmiertelne, a teraz oni również wyrwali się z objęć śmierci i zostaną z nami na zawsze! $!^{16}$

To oczywiście ilustracja instrumentalizacji tradycji romantycznej w dyskursie wladzy (niekoniecznie politycznej), w którym romantyzm jawi się jako jedyna droga kultury polskiej prowadząca do pisanych wielkimi literami - Piękna i Prawdy, w której zamiast uniwersalnych wartości intelektualnych podkreśla się jej „prasłowiańskość”, i która, by zaistnieć, potrzebuje datków społecznych.

\footnotetext{
${ }^{14}$ Ibidem, s. 11.

15 Ibidem, s. 10.

16 Ibidem, s. 17.
} 
Trzej wskrzeszeni mistrzowie to: Mickiewicz, Chopin, Matejko — jednak sposób ich funkcjonowania po wskrzeszeniu wydaje się wielce podejrzany. Wyglądajaj jak upiory, posługują się przyrządami kojarzącymi się z martwotą — kościaną fujarką, pędzlem z ludzkich włosów i kości, krwią jako atramentem. Ich twórczość krąży wokół motywów upiornych - Matejko maluje wampiryczną wersję Rejtana, zaś Mickiewicz recytuje czterowiersz zaczynający się od słów: „Pieśń ma była już w grobie”. W końcu okazuje się, że nie tylko ich sztuka, ale cale życie jest wampiryczne - żywią się krwią ludzi dostarczanych przez pracowników Ministerstwa Kultury.

Walkę z nimi musi stoczyć główny bohater komiksu, stanowiący niejako antytezę romantycznego bohatera. Już sam fakt, że jest prywatnym detektywem, skazuje go na żywot postaci literatury popularnej, do tego jest on detektywem „kanalizacyjnym” - specjalizuje się w odnajdywaniu przedmiotów zagubionych w kanałach, w których spędza większość czasu. Przypisany jest temu, co niskie, potencjalnie bezwartościowe, nieoficjalne.

Jest wielkim zwolennikiem literatury w płynie i przyjemności z niej czerpanej. Gdy znudzony przemówieniem Ministra zaśnie, przyśni mu się koszmar z czasów szkolnych, gdy dręczony był biografiami romantycznych mistrzów. Ten koszmar to wskazówka, że komiks wymierzony jest przeciwko „szkolnej” wersji romantyzmu, która czyni z niego strukturę martwą i upiorną.

Otto wyruszy na ratunek krytykowi porwanemu w celu uczynienia zeń pożywienia dla „mistrzów”. Okaże się zresztą, że wysysają oni przyprowadzanych nieszczęśników w pomieszczeniu połączonym z kanałami - jak się okazuje, górnolotne słowa o Prawdzie i Pięknie mają swoją podziemną antytezę. Później bohater odbędzie walkę z upiorami za pomocą drewnianych kołków, które wbije w ich serca. Na jego rękach skona krytyk literacki, odwołując niejako część swoich poglądów:

Teraz wiem, że te trupy z piekła rodem nie dadzą nam wartościowej sztuki... To epigoni, pogrobowcy, postmortemiści. My mamy czerpać z artystów, nie oni $z$ nas ${ }^{17}$.

Pokonawszy ostatniego z upiornych mistrzów - Chopina (przebijając jego serce w Kościele Świętego Krzyża), Otto zapali papierosa od jego płonącej ręki, pokazując w pewnym sensie swój stosunek do takiej tradycji literackiej.

Nie znaczy to, że Otto Bohater to przeciwnik sztuki w ogóle. W zakończeniu komiksu wskrzesza Aptekarza, by ten mógł kontynuować swój wielce pożyteczny proceder skraplania literatury i upowszechniania jej w ten sposób:

Trzeba ratować naszą kulturę, a on ma wyrobiony smak, nie będzie się zajmowal popłuczynami. On sprawi, że księgi zbłądzą pod strzechy. Taaa...

\footnotetext{
${ }^{17}$ Ibidem, s. 36.
} 
Młodziė̇ zapozna się z naszym dziedzictwem kulturowym i może wkrótce doczekamy się nowych Mistrzów ${ }^{18}$.

Nie ulega wątpliwości, że komiks Romantyzm to polemika z tym, co z romantyzmu uczyniono - z jego wersją cierpiętniczo-narodową, sztywno-szkolną, z której amputowano wszystko, co nie pasowało do tego wzorca - humor, codzienność, czytelniczą przyjemność. To sprzeciw wobec instrumentalizacji literatury — zarówno w imię celów Narodu, jak i arystokratyzmu sztuki. Sam utwór jest próbą wlania życia w tradycję romantyzmu, dialogu z nią w sztuce nieelitarnej i nieoficjalnej.

W moim tekście starałem się unikać terminu „literatura popularna” w odniesieniu do omawianych komiksów. Nie tylko dlatego, że jasne zdefiniowanie tego, czym jest dziś literatura popularna i czym właściwie różni się od innych literatur, to zadanie moim zdaniem bardzo trudne, jeżeli nie niemożliwe. Przede wszystkim — sztukę komiksu w Polsce, a zwłaszcza te dwa komiksy trudno uznać za popularne według kategorii zwykle tej literaturze przypisywanych (takich jak rynkowość, zamierzony masowy czytelnik czy niskie wymagania mu stawiane). Komiksy w Polsce to zjawiska raczej niszowe, ich nakłady nie różnią się od nakładów literatury uważającej się za wysoką — oczywiście mają inny adres wydawniczy, i bez wątpienia fakt ich publikacji poszerza obszar dyskusji o kulturze polskiej i miejscu, jakie zajmuje w niej tradycja dziewiętnastowieczna. Na pewno też pokazują jedną z metod, jakimi taką dyskusję można prowadzić.

Przy tej okazji warto powiedzieć jeszcze dwa słowa o obecności motywów romantycznych w niezwykle popularnym tekście kultury (który z kolei spełnia wymienione przeze mnie tradycyjne kryteria, pozwalające zaliczyć go do kultury popularnej) - grze komputerowej Wiedźmin. W jej akcie IV, którego akcja rozgrywa się w wiosce Odmęty, przywołano wprost motywy z literatury romantycznej — wśród napotkanych postaci znajdą się rywalizujący ze sobą młodzieńcy Julian i Adam (nazywany prześmiewczo „Ach-jak-ja-cierpię za-miliony”) oraz dwie zazdrosne siostry, z których jedna zabija drugą podczas zbierania malin. Ponieważ wszystko dzieje się w świecie fantasy, jedna zamieni się w północnicę, druga w południcę - jednak odniesienia do literatury romantycznej na tym się nie kończą, ponieważ aby zdjąć z nich klątwę, bard Jaskier użyje strof z Dziadów. Romantyzm funkcjonuje tu więc oczywiście jako pole zrozumialej (w zamierzeniu) dla wszystkich zabawy motywami literackimi ${ }^{19} \mathrm{w}$ stylu Andrzeja Sapkowskiego, co dodatkowo podkreślone zostało nadużywaniem przez jedną z sióstr określenia „romantyczny”. Ale został też udatnie włączony w klimat całego aktu, którego akcja dzieje się w baśniowej scenerii pośród pól złocących się łanami zboża i łąk

\footnotetext{
${ }^{18}$ Ibidem, s. 48.

${ }_{19}$ Według twórców gry, którzy opowiadają o produkcji Wiedźmina w dodatkach dołączonych do gry, motyw z Balladyny znany jest powszechnie każdemu, kto ukończył szkołę podstawową.
} 
zamieszkałych przez fantastyczne istoty. Twórcy Wiedźmina pokazali, że motywami $z$ literatury romantycznej można się we wspólczesnej kulturze popularnej bawić, odrzucając męczeńsko-narodowe stereotypy, a wykorzystując tylko jej, bardzo przecież uniwersalny, potencjal fantastyczno-baśniowy.

Wniosek z powyższych rozważań jest również taki, że wbrew pozorom, a ku uciesze takich zapalonych dziewiętnastowieczników (jak piszący te słowa), wiek XIX pozostaje wciąż istotnym odniesieniem dla kultury współczesnej, zarówno w jej wydaniu niszowym (komiksy), jak i popularnym (gra Wiedżmin). I wbrew przekonaniu o tym, że jest ogromnie nudny i ponury, jego odbicie w zwierciadle tekstów kultury współczesnej potrafi dać sporo rozrywki i wywołać uśmiech. 